\title{
FIELD ROBOTICS
}


This page intentionally left blank 


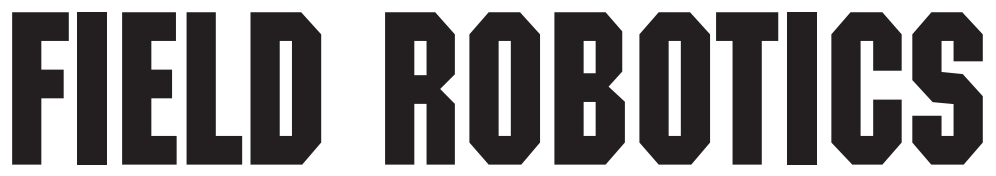

Proceedings of the 14th International Conference on Climbing and Walking Robots and the Support Technologies for Mobile Machines

University Pierre et Marie Curie (UPMC), Paris, France, 6 - 8 September 2011

\section{Editors}

\section{Philippe Bidaud}

Universite Pierre et Marie Curie, France

\section{Mohammad 0. Tokhi}

University of Sheffield, UK

\section{Christophe Grand}

Universite Pierre et Marie Curie, France

Gurvinder S. Virk

University of Gävle, Sweden 
Published by

World Scientific Publishing Co. Pte. Ltd.

5 Toh Tuck Link, Singapore 596224

USA office: 27 Warren Street, Suite 401-402, Hackensack, NJ 07601

UK office: 57 Shelton Street, Covent Garden, London WC2H 9HE

\section{British Library Cataloguing-in-Publication Data}

A catalogue record for this book is available from the British Library.

The front cover image has been provided by: Sami Ylonen, Helsinki University of Technology, Helsinki, Finland.

\section{FIELD ROBOTICS \\ Supplementary \\ Proceedings of the 14th International Conference on Climbing and Walking Robots and the Support Technologies for Mobile Machines}

Copyright (C) 2012 by World Scientific Publishing Co. Pte. Ltd.

All rights reserved. This book, or parts thereof, may not be reproduced in any form or by any means, electronic or mechanical, including photocopying, recording or any information storage and retrieval system now known or to be invented, without written permission from the Publisher.

For photocopying of material in this volume, please pay a copying fee through the Copyright Clearance Center, Inc., 222 Rosewood Drive, Danvers, MA 01923, USA. In this case permission to photocopy is not required from the publisher.

Printed in Singapore. 


\section{PREFACE}

Robotics has been an exciting field in engineering and natural sciences for many decades; it has held considerable fascination for researchers and scholars and many important contributions have been made by industrial robots in various manufacturing tasks such as assembly, welding, painting, and material handling. In recent times, we have been witnessing the emergence of new service robots which are intended to perform a variety of tasks in new environments such as search and rescue, surveillance, exploration, security missions and surgical operations as well as provide assistance to various users.

Field robotics aims to bring technologies that allow autonomous systems to assist and/or replace humans performing tasks that are difficult, repetitive, unpleasant, or take place in hazardous environments. These robotic systems will bring sociological and economic benefits through imporved human safety, increased equipment utilisation, reduced maintenance costs and increased production.

CLAWAR 2011 is the fourteenth in a series of international conferences on Climbing and Walking Robots and the Support Technologies for Mobile Machines. The aim of the conference is to provide an open forum where researchers, scientists, engineers and practitioners from throughout the world can come together to present and discuss the latest achievements, future challenges and exciting applications for mobile service machines in general, and climbing and walking robots in particular. The proceedings of CLAWAR 2011 include state of the art research and development findings presented during the CLAWAR 2011 conference in 119 technical presentations by authors from 28 countries covering the five continents.

The editors would like to thank members of the International Program Committee, International Advisory Committee and National Organising Committee for their efforts in reviewing the submitted papers, and the authors in addressing the comments and suggestions of the reviewers in their final submissions. It is intended that the CLAWAR 2011 proceedings will be a valuable source of reference for research and development in mobile robotics.

P. Bidaud, M. O. Tokhi, C. Grand, G. S. Virk 


\section{CONFERENCE ORGANISERS}

\section{UPMC}

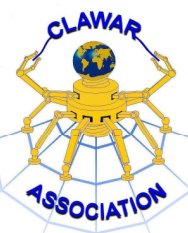

University Pierre et Marie Curie

Paris, France

\section{CLAWAR Association}

A non-profit making membership based professional organization serving the robotics community www.clawar.org 


\section{CONFERENCE COMMITTEES}

\section{General Chairs and Programme Chairs}

of Fourteenth International Conference on Climbing and Walking Robots and the Support Technologies for Mobile Machines

P. Bidaud (General Chair)

M. O. Tokhi (Program Chair)

C. Grand (Program Vice-Chair)

G. S. Virk (IAC Chair)
- University Pierre et Marie Curie, France

- University of Sheffield, UK

- University of Tsukuba, Japan

- University of Gävle, Sweden

\section{International Advisory Committee (IAC)}

of Fourteenth International Conference on Climbing and Walking Robots and the Support Technologies for Mobile Machines

H. Levent Akin - - Turkey

Manuel Armada $\quad-$ Spain

Yvan Baudoin $\quad-$ Belgium

Karsten Berns — - Germany

Bryan Bridge $\quad-$ UK

Anibal T de Almeida - Portugal

H. Fujimoto - Japan

Krzysztof Kozlowski - Poland

Giovanni Muscato - Italy

Lakmal Seneviratne - UK

Ming Xie

- Singapore 


\section{International Programme Committee (IPC)}

of Fourteenth International Conference on Climbing and Walking Robots and the Support Technologies for Mobile Machines

\begin{tabular}{|c|c|c|c|}
\hline Ahmadabadi M. N. & - Iran & Latif Shabgahi R. & - Iran \\
\hline Alam M. S. & - Bangladesh & Lee $\mathrm{S}$. & - Korea \\
\hline Aldbrez F. M. & - UK & Lefeber D. & - Belgium \\
\hline Althoefer K. & - UK & Lewis M. A. & - USA \\
\hline Arkin R. & - USA & Lopez-Coronado J. & - Spain \\
\hline Azad A. K. M. & - USA & Luo R. C. & - Taiwan \\
\hline Billingsley J. & - Australia & Ma H. & - China \\
\hline Bonsignorio $\mathrm{F}$. & - Italy & Marques L. & - Portugal \\
\hline Bouazza-Marouf K. & - UK & Mochiyama H. & - Japan \\
\hline Cameron S. & - UK & Mohamed Z. & - Malaysia \\
\hline Cheng H. & - China & Molfino R. & - Italy \\
\hline Chevallerau C. & - France & Moon S. & - Korea \\
\hline Chew C-M. & - Singapore & Nakamura T. & - Japan \\
\hline Chugo D. & - Japan & Pratihar D. K. & - India \\
\hline Cruse H. & - Germany & Quinn R. & - USA \\
\hline Dai J. & - UK & Rachkov M. & - Russia \\
\hline Dehghani A. & - UK & Salichs M. A. & - Spain \\
\hline de Santos P. G. & - Spain & Sano A. & - Japan \\
\hline Dillmann R. & - Germany & Santos V. & - Portugal \\
\hline Dodd T. J. & - UK & Sattar T. P. & - UK \\
\hline Dubowsky S. & - USA & Schilling K. & - Germany \\
\hline Dunbabin M. & - Australia & Shaheed M. H. & - UK \\
\hline Dutra M. S. & - Brazil & Sharma S. K. & - UK \\
\hline Dutta A. & - India & Siddique N. H. & $-\mathrm{UK}$ \\
\hline Fontaine J-G. & - Italy & Silva F. & - Portugal \\
\hline $\mathrm{Fu} \mathrm{Y.}$ & - China & Steinicke L. & - Belgium \\
\hline Fukuda T. & - Japan & Tenreiro Machado J. & - Portugal \\
\hline Garcia E. & - Spain & Tosun $\mathrm{O}$ & - Turkey \\
\hline Goher K. M. & - Oman & Vitko A. & - Slovakia \\
\hline Gradetsky V. & - Russia & Waldron K. J. & - USA \\
\hline Gross R. & - UK & Watanabe K. & - Japan \\
\hline Hossain M. A. & - UK & Yigit A. & - Kuwait \\
\hline Howard D. & - UK & Ylonen S. & - Finland \\
\hline Ion I. & - Romania & Zecca M. & - Japan \\
\hline Jatsun S. F. & - Russia & Zhong Z. W. & - Singapore \\
\hline Kadar E. E. & - UK & Zhou C. J. & - Singapore \\
\hline Kiriazov P. & - Bulgaria & Zielinska T. & - Poland \\
\hline
\end{tabular}




\section{National Organising Committee}

of Fourteenth International Conference on Climbing and Walking Robots and the Support Technologies for Mobile Machines
F. B. Amar
M. Mouaddib
C. Chevallereau
J. B. Mouret
S. Doncieux
F. B. Ouezdou
S. Lacroix
V. Pasqui
B. Gas
F. Plumet
A. Godin
B. Thuilot
T. Hamel
S. Zeghloul
J. Morillon 
This page intentionally left blank

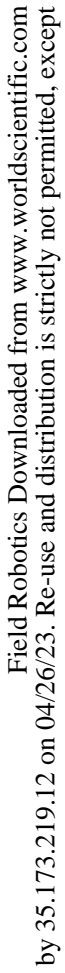




\section{TABLE OF CONTENTS - SUPPLEMENTARY}

Preface. $\mathrm{V}$

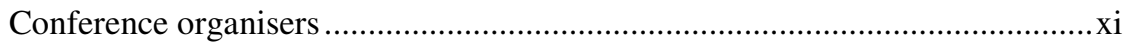

Conference committees ..................................................................................

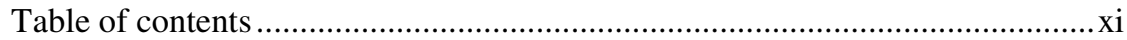

\section{Section-S1: Assistive Robots - Supplementary}

Tracking control to human gait of lift-type walking assist robot using range sensor. 3

Y. Ochi, K. Terashima, K. Kubo, T. Miyoshi, K. Kakihara, T. Iwade, T.Yamamoto and T. Sakakibara

Control strategy and structure identification for efficient motion rehabilitation

P. Kiriazov, G. Nikolova, I. Veneva and N. Zlatov

Development of standing up and walking motion apply for nursing-care assistant robot

Y. Sakaida, D. Chugo and R. Ikeura

Development of the ATLAS lower-limb active orthosis.

E. Garcia, D. Sanz-Merodio, F. Sanchez, J. Pestana, J. C. Arevalo and P. G. de Santos

\section{Section-S2: Plenary Presentations}

An overview of Canadian space robotics activities

E. Dupuis

Human-friendly robotics

O. Khatib

Robots with humans

R. Chatila

Author index-Supplementary 